\title{
Diagnostic and Prognostic Significance of Histidine-Rich Glycoprotein in Acute Lymphoblastic Leukemia
}

\author{
Manal Basyouni Ahmed1,2*, Ebtehal Almogbel ${ }^{3}$, Iman Khirry'2, Sara Hassan", Tarek Salem5, \\ Aliaa Saeed 6
}

${ }^{1}$ Medical Biochemistry Department, Faculty of Medicine, Qassim University, Al-Mulida, KSA

${ }^{2}$ Medical Biochemistry Department, Faculty of Medicine, Ain Shams University, Cairo, Egypt

${ }^{3}$ Family Medicine, Faculty of Medicine, Qassim University, Al-Mulida, KSA

${ }^{4}$ Clinical Pathology, Faculty of Medicine, Ain Shams University, Cairo, Egypt

${ }^{5}$ Clinical Pathology, Faculty of Medicine, Qassim University, Al-Mulida, KSA

${ }^{6}$ Internal Medicine (Hematology Department), Faculty of Medicine, Ain Shams University, Cairo, Egypt

Email:*manal_basiony@yahoo.com

How to cite this paper: Ahmed, M.B., Almogbel, E., Khirry, I., Hassan, S., Salem, T. and Saeed, A. (2017) Diagnostic and Prognostic Significance of Histidine-Rich Glycoprotein in Acute Lymphoblastic Leukemia. Open Journal of Blood Diseases, 7, 16-28.

https://doi.org/10.4236/ojbd.2017.71002

Received: November 7, 2016

Accepted: December 27, 2016

Published: December 30, 2016

Copyright $\odot 2017$ by authors and Scientific Research Publishing Inc. This work is licensed under the Creative Commons Attribution International License (CC BY 4.0).

http://creativecommons.org/licenses/by/4.0/

c) (i) Open Access

\begin{abstract}
Background: Histidine-rich glycoprotein (HRG), a multifunctional plasma protein, has a regulatory role in homeostasis, angiogenesis, and immunity; which in turn could greatly affect tumor control and metastasis. Objectives: To assess the possible role of HRG in acute lymphoblastic leukemia (ALL) tumorgenesis and follow-up. Design and Methods: HRG was quantitatively measured in serum by ELISA and its expression was assessed by real-time PCR (qPCR) in 35 patients with ALL and compared to same 25 ALL patients after induction therapy and 30 age and sex matched healthy control subjects. Results: HRG-serum protein (at cutoff value $63.55 \mathrm{pg} / \mathrm{ml}$ ) and HRG-RNA (at cutoff value 0.955 ) were positive in all ALL patients before therapy, but in only $76 \%$ after therapy for HRG-protein and $60 \%$ for HRG-RNA and they could not be detected in the control group; $\mathrm{P}<0.001$. Additionally, the serum HRG level showed a significant positive correlation with its expression level, bone marrow blast percentage, peripheral blood blast count, $\mathrm{P}<0.01$. Also its serum and expression levels were positively related to the poor risk Philadelphia chromosome; $\mathrm{P}<0.01$. Conclusions: HRG (protein and RNA) might be considered as a novel diagnostic and prognostic marker in ALL. HRG-serum protein level, detected by simple methodology of ELISA, has more significant advantages than its expression level, motivating its application in large clinical studies as a potential marker.
\end{abstract}

\section{Keywords}

Acute Lymphoblastic Leukemia, Histidine-Rich Glycoprotein and Serum 
Markers

\section{Introduction}

Acute lymphoblastic leukemia (ALL) is a highly heterogeneous disease comprising many entities for which distinct treatment strategies are pursued. Treatment of ALL remains one of the most challenging adult malignancies, especially with respect to therapy [1]. The inherent heterogeneity of ALL requires an accurate assessment of risk to aid treatment decisions. In the past, the classic prognostic factors were age, presenting white blood cell (WBC) counts, cytogenetic abnormalities and upfront response to induction therapy. One of the strongest adverse prognostic features is the presence of the Philadelphia chromosome $t(9 ; 22)$ [2]. Although more than $80 \%$ of adult patients with Philadelphia chromosome (Ph)-negative ALL achieve complete remission (CR) with conventional induction therapy, their 5 -year survival is only $30 \%-40 \%$. Leukemia relapse is the most common cause of treatment failure in ALL [3].

Histidine-rich glycoprotein (HRG) is, a $\sim 75-\mathrm{kDa}$ single polypeptide chain protein, synthesized by the liver and secreted from activated platelets [4]. It is a multidomain protein displaying two cystatin-like regions of the $\mathrm{N}$-terminus and a histidine-rich region (HRR) flanked by proline-rich regions (PRR) closer to the C-terminus [5]. HRG could interact with many ligands, including heparin, phospholipids, plasminogen, fibrinogen, immunoglobulin G, C1q, heme, and $\mathrm{Zn}^{2+}$ [6]. Through these interactions, HRG could function as an adaptor molecule and thereby modulates numerous important biologic processes, such as immunity, angiogenesis, cell adhesion, cell proliferation, and remodeling of the extra cellular matrix (ECM). Many of these functions are involved in tumor progression and antitumor response [7].

Some studies reported the proangiogenic effect of HRG through its high binding affinity to thrombospondin and interfering with TSP-CD36-mediated antiangiogenic signaling which inhibits angiogenesis induced by basic fibroblast growth factor [8]. While other studies suggested the antiangiogenic activity of HRG as it could inhibit endothelial cell adhesion and migration, block angiogenesis and induce apoptosis in endothelial cells [9]. Kärrlander and his colleagues [10] found that the quality of the vasculature is impaired by increasing expression of HRG in mouse malignant glioma cells. Meanwhile, Rolny et al. [11] reported that angiogenesis was improved in HRG-transduced tumors, including increased vessel perfusion and percentage of priest covered vessels. Moreover, the presence of HRG in the stroma of most tumor biopsies, indicates that its effects are likely dependent on their concentration in the tumor and type of tumor [12].

Previous studies evaluated HRG as a useful tool in several types of cancers, but rare of them were conducted in ALL, so the aim of the current study was to investigate HRG by two different approaches as ELISA assay and real-time PCR, 
and evaluate its diagnostic and prognostic value in ALL patients.

\section{Patients and Methods}

\subsection{Subjects}

The current case-control study was conducted on 65 adult subjects (age $\geq 18$ years) including 35 ALL patients, and 30 healthy control subjects. All patients were recruited from the Hematology and Clinical Oncology Unit, Internal Medicine Department, Faculty of Medicine, Ain Shams University, Cairo, Egypt in the period from July 2014 to March 2015. An informed consent was taken from all subjects participating in the present study according to declaration of Helsinki and was approved by the Research Ethics Committee of Ain Shams University, Cairo, Egypt.

Leukemia was diagnosed and classified according to the criteria of the FrenchAmerican-British (FAB) Cooperative Group [13].

\subsubsection{The Subjects Enrolled in This Study Were Divided into the} Following Groups

- Group-I (Malignant Group): Included 35 adult patients with newly diagnosed acute lymphoblastic leukemia (23 males and 12 females) with mean age of $38.8 \pm 8.1$ years, classified based on FAB classification into 23 patients having pre-B-ALL ( 8 with +ve Philadelphia chromosome), 5 patients as having B-ALL and 7 patients as having T-ALL (4 with +ve Philadelphia chromosome).

- Group-II (Follow-Up Group): Included 25 patients with ALL, they are the same individuals of group I after receiving induction chemotherapy protocol. Of them, unfortunately 10 have succumbed their illness during induction. The remaining 25 patients were segregated into chemotherapy responsive and chemorefractory patients in accordance with the complete remission criteria that will be detailed below.

- Group-III (Control Group): Included 30 healthy controls subjects (21 males and 9 females) with mean age of $40.5 \pm 3.6$ years with a complete normal demographic data.

\subsubsection{Inclusion Criteria}

- Adults (age $\geq 18$ years).

- Newly diagnosed ALL patients.

\section{Exclusion criteria:}

- Age $<18$ years.

- Relapsed or refractory ALL patients who have received prior chemotherapy protocols.

\subsubsection{Plan of Treatment in ALL Patients}

- Patients were given eight induction-consolidation courses of alternating hyper-CVAD with high-dose methotrexate and cytarabine. Briefly, the treatment regimen was as follows. Odd courses $(1,3,5,7)$ were hyper-CVAD, while 
Even courses $(2,4,6,8)$ included high-dose methotrexate and cytarabine: 200 $\mathrm{mg} / \mathrm{m}^{2}$ methotrexate. Addition of tyrosine kinase inhibitor namely imatinibmesylate; at a dose of $400 \mathrm{mg}$ a day was done when the patient was proved to be pheladelphia positive ALL [14].

\subsubsection{Definition of Response}

Response assessment was done at day 21 of course 1, if patient did not achieve complete remission, then he/she proceeded to course 2 and the response was assessed at day 21 of course. Response criteria were defined as no evidence of leukemic blasts in the $\mathrm{BM}(<5 \%)$, complete resolution of extramedullary manifestations, and recovery of peripheral cell counts [15].

Follow up period: Patients were followed up from the beginning of induction with course 1 to the end of course 2 .

\subsection{Methods}

\subsubsection{Sample Collection}

Blood samples $(5-10 \mathrm{ml})$ were drawn from all subjects before any therapeutic intervention and after 3 weeks of completed induction therapy. Five-milliliters blood were collected into tubes without anticoagulant for serum samples; another $5 \mathrm{ml}$ blood were collected into EDTA-anticoagulated tubes for RNA extraction and PCR protocol. Serum and RNA samples were separated and then stored at $-80^{\circ} \mathrm{C}$ until subsequent processing and measurements.

\subsubsection{Assay Procedures}

HRG concentration was measured using enzyme-linked immunosorbent assay (ELISA) kit (Catalog No: E2267h; Wuhan EIAab Science Co., Ltd, China). The assay employs the quantitative sandwich enzyme immunoassay technique according to the steps described by the manufacturer.

\subsubsection{RNA Isolation and Real-Time Polymerase Chain Reaction (qPCR)}

Aliquots of plasma from peripheral blood were processed using RNA extraction kits supplied by Ambion (nirvana ${ }^{\mathrm{Tm}}$ Paris ${ }^{\mathrm{Tm}} \mathrm{Kit}$ ). Extraction was carried on under complete sterile conditions in a level II Biosafety cabinet (Lobonco), steps were carried out according to the manufacture's instructions. Ethanol was added to the samples and they were passed through a filter cartridge containing a glass, fiber filter immobilizes the RNA. The filter was then washed few times and finally the RNA was eluted with a low ionic strength solution. The RNA purity and concentration were determined by spectrophotometric measurement of absorbance at 260 and $280 \mathrm{~nm}$.

The reverse transcription reaction was carried out in $20 \mu \mathrm{L}$ reaction mixture using $2 \mu \mathrm{g}$ of RNA by using higher capacity RNA to c-DNA master mixsupplied by (Applied Bio-system, ABI). Real-time PCR was performed using a real-time PCR 7500 fast ABI thermal cycler (Applied Bio-system, USA), selecting the comparative CT as quantitation method. A final volume of $20 \mu \mathrm{L}(10 \mu \mathrm{L}$ of Quantifast SYBR Green PCR master mix, $1 \mu \mathrm{L}$ of each primer, up to $8 \mu \mathrm{L}$ diluted 
c-DNA, $\mathrm{H}_{2} \mathrm{O}$ as required) was wanted. An initial denaturation at $95^{\circ} \mathrm{C}$ for 10 minutes, then 40 cycles were done. Each cycle consisted of denaturation at $94^{\circ} \mathrm{C}$ for 15 seconds, annealing at $60^{\circ} \mathrm{C}$ for 25 seconds and elongation at $72^{\circ} \mathrm{C}$ for 20 seconds. The following primer sequences were used for Histidine rich glycoprotein (HRG) (forward, 5'GATCATCATCATCCCCACAAG-3; reverse, 5 '-GGGTCACAAGGTCCATAGTC-3', GenBank: NM_000412.2). B-actin (forward, 5 '-AGCGGG AAA TCG TGC GTG-3'reverse, 5 '-CAG GGT ACA TGG TGC C-3) which was used as an endogenous reference. Bio-Rad software was used to calculate threshold cycle $(\mathrm{Ct})$ values for the target gene and for the reference gene (B-actin). The expression values of the tumor samples are presented as a fold expression in relation to the control sample; the actual values were calculated using the $2^{-\Delta \Delta \mathrm{Ct}}$ equation, where $\Delta \Delta \mathrm{Ct}=[\mathrm{Ct}$ Target $-\mathrm{Ct} \mathrm{B}$-actin] (tumor sample) - [Ct Target - Ct B-actin] (control sample).

\subsubsection{Statistical Analysis}

The analysis was done using the Statistical Package for the Social Sciences (SPSS software version 19, SPSS Inc., Chicago, IL). Statistical comparisons were made using parametric test, ANOVA (followed by Post Hoc test) or nonparametric Mann-Whitney U (to compare two groups) and Kruskal-Wallis tests (to compare three groups). Chi-square test was used to compare quantitative parameters between groups. Correlation between different variables was performed by Pearson's correlation coefficient. Statistical significance was set at a value of $\mathrm{p}<$ 0.05 . The best cutoff value that maximizes sensitivity and specificity and differentiates acute lymphoblastic patients from controls was calculated by using the Receiver Operating Characteristic (ROC) curve, which was constructed by calculating the true positive fraction (sensitivity percent) and false positive fraction (100-specificity) of markers at several cut-off points. Positive predictive value was calculated as percent of truly positive patients while negative predictive value was calculated as percent of truly subjects that don't have the disease.

\section{Results}

The median percentage of bone marrow leukemic blasts in leukemic patients was $88.0 \%$ (range from $32 \%$ to $98 \%$ ), while peripheral blood leukemic blasts it was $58.0 \%$ (range from $23 \%$ to $95 \%$ ), Table 1 . The leukemic patients before therapy showed higher HRG levels as detected by ELISA $(657.9 \pm 203.8 \mathrm{pg} / \mathrm{ml}$; range $264.0-931.5 \mathrm{pg} / \mathrm{ml})$ and by qPCR $(5.51 \pm 3.5$; range 1.7 - 13.1) compared to control group ( $45.6 \pm 8.0 \mathrm{pg} / \mathrm{ml}$; range $37.0-59.0 \mathrm{pg} / \mathrm{ml}$ for HRG-serum protein and $0.41 \pm 0.21$; range $0.14-0.9$ for HRG-RNA), $\mathrm{p}<0.01$. Moreover, HRG-serum protein (mean $185.4 \pm 114.1 \mathrm{pg} / \mathrm{ml}$; range $22.0-377.0 \mathrm{pg} / \mathrm{ml}$ ) and HRG-RNA (mean 1.2 \pm 0.97 ; range 0.13 - 0.34) in ALL patients after therapy had a significantly lower level than those patients before therapy $(\mathrm{P}<0.01)$, and a significantly higher level than normal group for HRG-serum protein only $(\mathrm{P}<$ 0.01 ), Figure 1 . The best cutoff value for HRG-serum protein levels in ALL detected by ROC curves, considering healthy subjects as control group, was 63.55 
$\mathrm{pg} / \mathrm{ml}$ with $90.0 \%$ sensitivity and $100.0 \%$ specificity, and for HRG-RNA was 0.955 with $83.3 \%$ sensitivity and $100 \%$ specificity $(\mathrm{p}<0.01)$, Figure 2 and Table 2. Moreover, HRG positivity rates detected by both methods was $100 \%$ in ALL

Table 1. Clinicopathological parameters of ALL patients.

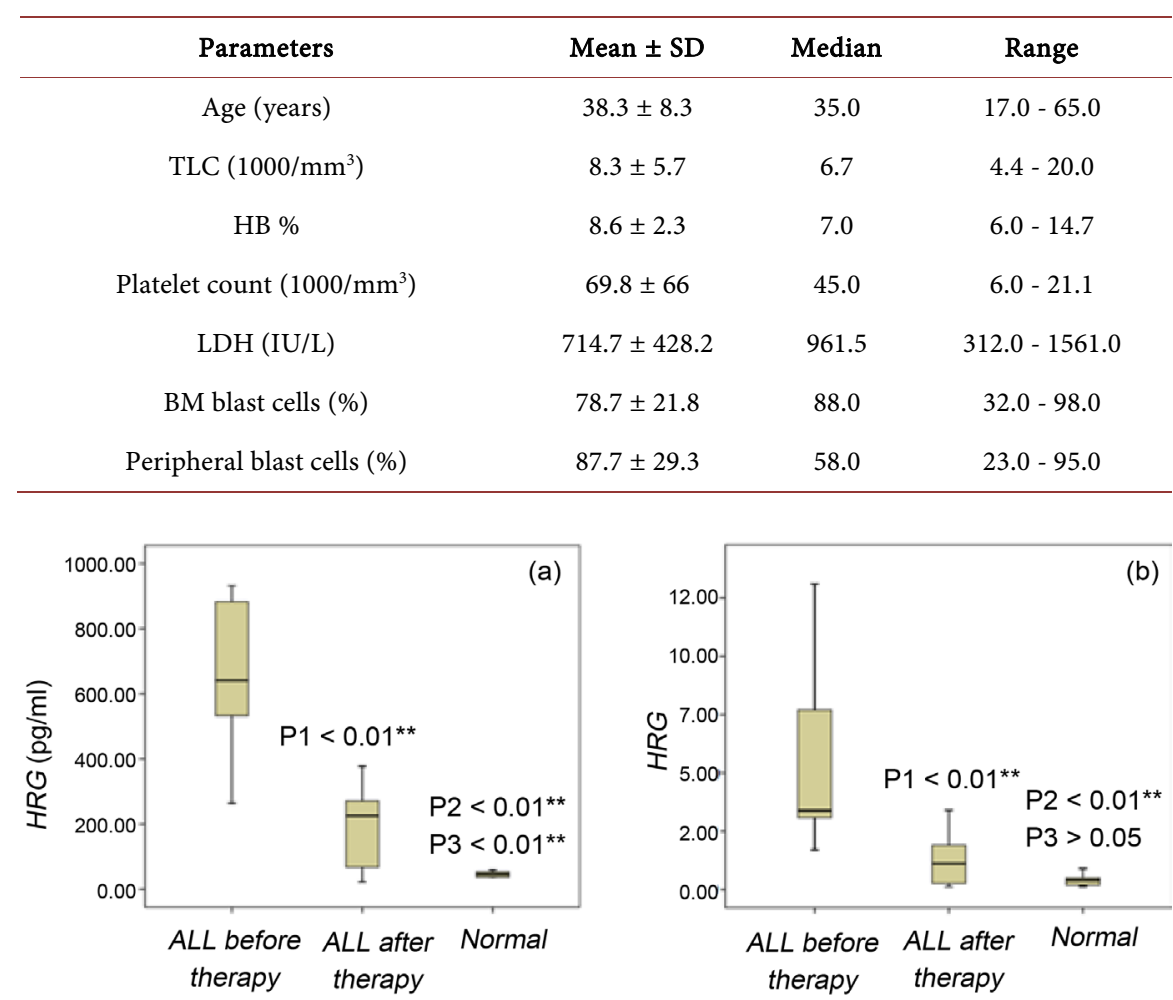

Figure 1. Serum HRG mean level detected by ELISA method (a) and qPCR (b) in ALL patients before and after therapy and control groups. ( $\mathrm{p} 1=$ after versus before therapy, $\mathrm{p} 2=$ normal group versus ALL before therapy and $\mathrm{p} 3$ = normal group versus ALL after therapy ${ }^{\star *} \mathrm{P}<0.01$ is highly significant. $\mathrm{P}>0.05$ is non-significant).

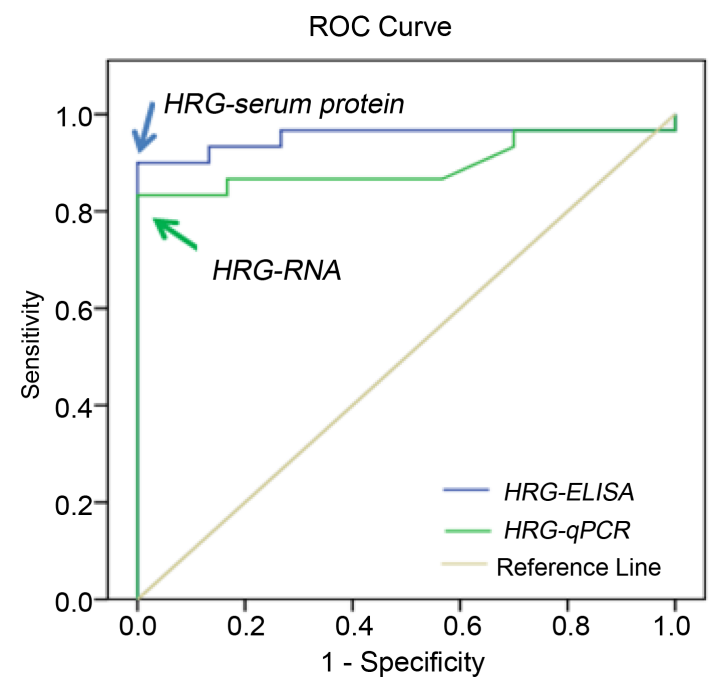

Figure 2. ROC curves for serum HRG-serum protein and HRG-RNA to discriminate between ALL patients and normal control group. The arrows denote best cutoff points of HRG-serum protein at $63.55 \mathrm{pg} / \mathrm{ml}$ and HRG-RNA at $0.955, \mathrm{P}<0.01$. 
patients before therapy and $0.0 \%$ in the normal group, while in follow-up group it was $76.0 \%$ for in HRG-serum protein and $60.0 \%$ for HRG-RNA ( $\mathrm{P}<0.001$ ), Figure 3. No significant differences between ALL subtypes and HRG, however, the HRG protein level was significantly higher in AAL patients with +ve Philadelphia chromosome $(\mathrm{P}<0.01)$ and both HRG protein and RNA protein were significantly high in ALL patients who died during the course of treatment compared to those had complete remission $(\mathrm{P}<0.01)$, Table 3 . Furthermore, HRG protein showed a significant negative correlation with platelets $(\mathrm{P}<0.01)$, HB\% $(\mathrm{P}<0.05)$ and significant positive correlations with its expression level, LDH, BM blast cells and peripheral blast cells $(\mathrm{P}<0.01)$, while HRG-RNA showed significant positive correlations only with $\mathrm{LDH}(<0.05)$ and peripheral blast cells $(\mathrm{P}<0.01)$, Table 4 .

\section{Discussion}

Histidine-rich glycoprotein (HRG) is a multifunctional plasma protein with two cystatin-like domains and a wide spectrum of targets and functions [16]. Extensive research studied the potential role of HRG in carcinogenesis, however, its effect on overall survival remains to be clearly determined. In the current study,

Table 2. Diagnostic performance of serum HRG-serum protein and HRG-RNA from patients with acute lymphoblastic leukemia and normal control group.

\begin{tabular}{ccccccc}
\hline Variable & Cut-off points & Sensitivity & Specificity & NPV & PPV & AUC \\
\hline HRG-serum protein & $63.55 \mathrm{pg} / \mathrm{ml}$ & $90.0 \%$ & $100 \%$ & $83.3 \%$ & $100 \%$ & 0.953 \\
HRG-RNA & 0.955 & $83.3 \%$ & $100 \%$ & $75.0 \%$ & $100 \%$ & 0.896
\end{tabular}
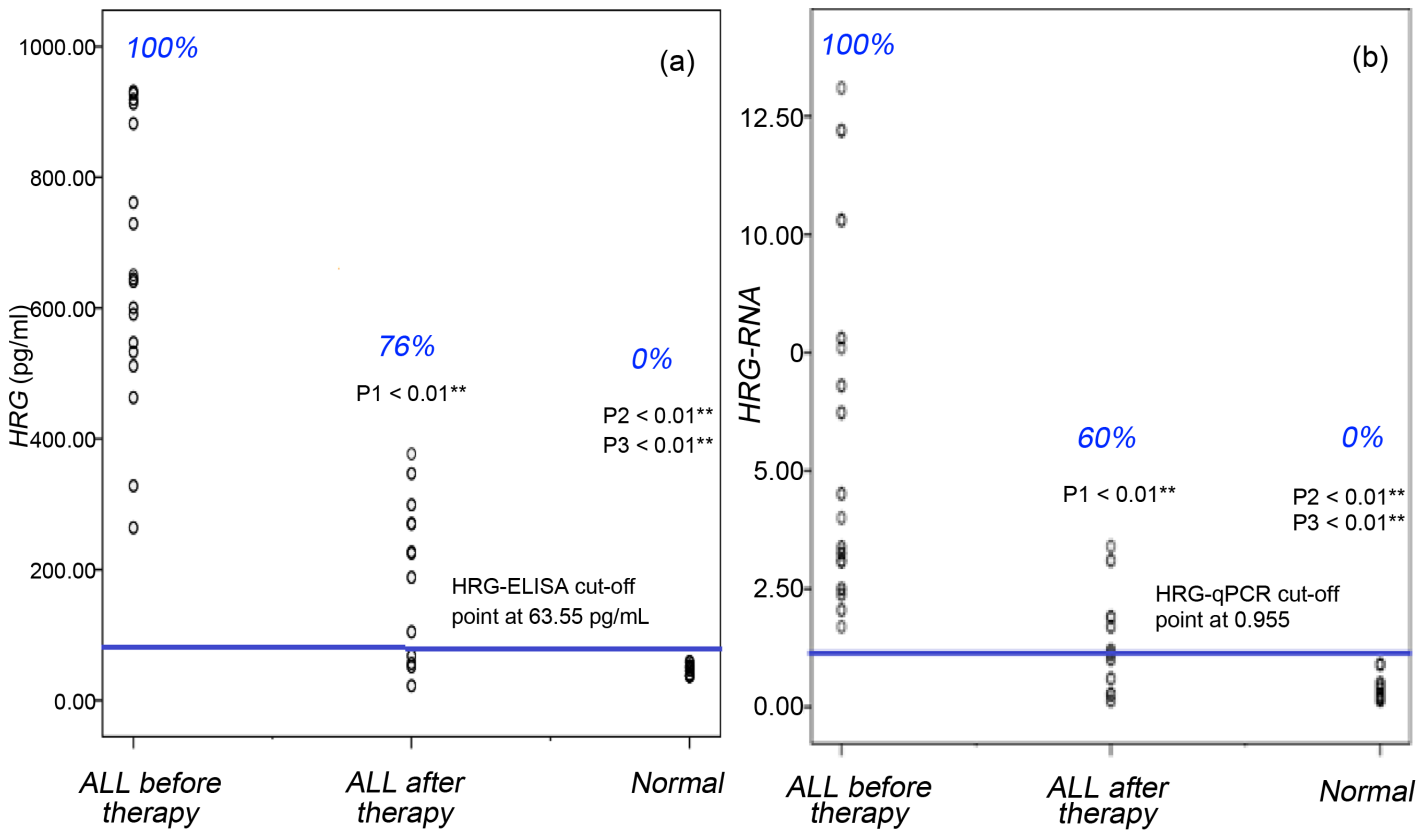

Figure 3. Positivity rate of patients of serum HRG-serum protein (a) and HRG-RNA (b) above the cutoff value in the different studied groups. ( $\mathrm{p} 1=$ after versus before therapy, $\mathrm{p} 2$ = normal group versus ALL before therapy and $\mathrm{p} 3=$ normal group versus ALL after therapy ${ }^{\star *} \mathrm{P}<0.01$ is highly significant). 
Table 3. Relation between mean rank of HRG serum level and RNA expression with clinicopathological factors in the ALL patients.

\begin{tabular}{ccc}
\hline Clinicopathological factors & HRG serum level & HRG-RNA Expression \\
\hline Type of ALL; & 19.24 & 17.74 \\
Pre-B-ALL (23) & 18.5 & 20.5 \\
B-ALL (5) & 15.2 & 17.55 \\
T-ALL (7) & $\chi 2: 1.06$ & $\chi 2: 0.2$ \\
& $\mathrm{p}: 0.5$ & $\mathrm{p}: 0.8$ \\
Chromosomal abnormalities; & 13.83 & 16.28 \\
Normal (23) & 26.0 & 21.29 \\
+ve Philadelphia chromosome & $\chi 2: 11.1$ & $\chi 2: 1.89$ \\
(12) & ${ }^{*} \mathrm{p}: 0.001$ & $\mathrm{p}: 0.16$ \\
ALL patients & 13.48 & 13.16 \\
Complete remission (25) & 29.30 & 30.1 \\
Dead patients (10) & $\chi 2: 17.0$ & $\chi 2: 19.5$ \\
& ${ }^{*} \mathrm{p}: 0.001$ & ${ }^{*} \mathrm{p}: 0.001$ \\
\hline
\end{tabular}

$\mathrm{P}^{*}$ Significant difference between types by applying non parametric Mann-Whitney U (to compare Chromosomal abnormalities) and Kruskal-Wallis tests (to compare Types of ALL).

Table 4. Pearson correlation between HRG-ELISA and HRG-qPCR and other parameters.

\begin{tabular}{ccc}
\hline Parameters & HRG-serum protein & HRG-RNA \\
\hline Age & 0.08 & -0.19 \\
TLC & $0.489^{\star}$ & -0.08 \\
Platelet count & $-0.56^{* *}$ & 0.02 \\
HB\% & $-0.38^{\star}$ & 0.34 \\
LDH & $0.6^{* *}$ & $0.47^{* *}$ \\
Peripheral Plast Cells & $0.87^{\star *}$ & $0.42^{\star}$ \\
BM Plast Cells & $0.76^{* *}$ & 0.16 \\
HRG-RNA & $0.75^{\star *}$ & $\ldots \ldots .$. \\
\hline
\end{tabular}

${ }^{*} \mathrm{P}$ value $<0.05$ is significant, ${ }^{* *} \mathrm{P}$ value $<0.01$ is highly significant.

we tried to detect HRG by two strategic approaches; ELISA and qPCR to investigate their values in ALL patients. We found that HRG-serum protein and HRG-RNA were significantly higher in ALL patients before therapy compared to control group. A significant reduction in HRG was observed in patients after therapy compared to at diagnosis, however, this level was still significantly higher than the normal group for only HRG-serum protein. According to ROC curve which discriminated ALL patients from healthy persons, none of the healthy control group expressed HRG detected by both methods above that calculated cutoff value giving up $100 \%$ specificity. Meanwhile, all ALL patients before thereby showed $100 \%$ sensitivity while after therapy, they were $76.0 \%$ positive for HRG-serum protein and $60.0 \%$ for HRG-RNA. Similar to our results, Matboli et al. [17] revealed that HRG tissue RNA and serum protein could be considered as promising novel markers for prediction of breast cancer prognosis with 71.7\% sensitivity and $93.3 \%$ specificity for HRG tissue RNA and $86.7 \%$ sensitivity and $80 \%$ specificity for HRG serum protein. Moreover, Klenotic et al. [18] demon- 
strated that HRG expression was increased by glioma cells in both subcutaneous and orthotopic brain tumor models resulted in an increase in tumor size and angiogenesis, possibly through interfering with the antiangiogenic activity of vasculostatin. On the other hand, HRG has been found to be reduced in the serum of alpha fetoprotein-negative hepatitis B virus-related hepatocellular carcinoma [19] and down regulated in endometrial carcinoma [20]. Moreover, Wu et al. [21] reported that fucosylated HRG levels were significantly higher in patients with stage III ovarian cancer compared to normal and benign donors but was not significantly higher in patients with stage I/II disease. HRG's antitumor activity has been ascribed due to its immune modulator functions and its effects on tumor vessels. The contradiction of the previous reports about pro- and antiangiogenic properties of HRG might be owing to its multi-domain structure and the activities of its proteolytically-released fragments, notably the histidine-proline rich region [22] and different experimental systems used [23]. Rolny et al. [11] assumed that HRG affects other cell types, such as macrophages, known to regulate angiogenesis and HRG might regulate tumor angiogenesis indirectly through tumor-associated macrophages.

HRG level was still high in follow-up ALL patients despite their complete remission (blast cells were around 5\% and the rest of cells were normal), that had a statistically significant difference between HRG-serum protein levels after therapy and normal subjects. We previously explained it probably by persistence of residual tumor cells leading to relapse if no further additional consolidation chemotherapy was administered. This may highlight the molecular biology-based methods with a greater prognostic significance than conventional criteria for the detection of remission [24] [25]. Nagafuji et al. [26] reported that chemotherapy should be continued as follow up therapy in ALL even with good prognosis in order to prevent leukemia relapse. However, patients with less favorable prognosis should be treated more aggressively. Although allogeneic hematopoietic stem cell transplantation (HSCT) for patients with ALL in complete remision is much more intensive than multi-agent combined chemotherapy, it is associated with increased morbidity and mortality when compared with such chemotherapy. Minimal residual disease (MRD) status has been proven to be a strong prognostic factor for adult patients with Ph-negative ALL.

We also found a significant correlation between HRG-serum protein and its expression levels. Regarding their importance as a prognostic marker, significant positive correlations were excitsed between HRG-RNA and LDH, and peripheral blast cells. While HRG-serum protein showed more prognostic capacity through its additionally significant positive correlations with BM blast cells and significant negative correlations with platelets and HB\%. Meanwhile, the HRG protein level was significantly higher in AAL patients with +ve Philadelphia chromosome. However, both HRG protein and RNA were significantly high in ALL patients who died during the course of treatment compared to those had complete remission. Contrary to our results, Roberts et al. [27] found that HRG was weak-associated with improved overall survival in a Phase III trial that compared 
patients with pancreatic cancer. However, they explained this weak positivity of HRG as a prognostic marker due to its anti-angiogenic properties as the patients in trial phase were receiving anti-VEGF monoclonal antibody. Moreover, Zhang et al. [28] suggested the negative regulatory role HRG on hepatocellular carcinoma cell line through regulating cell proliferation via the Erk1/2 signaling pathway. Mantovani and Sica [29] revealed the antitumor activity of HRG as it is not only increased tumor infiltration by antigen-presenting DCs, cytolytic NK cells, and cytotoxic T-lymphocytes but also enhances their antigen presentation and tumor cell lysis potential, immune changes known to inhibit tumor growth. The possible, increasing levels of HRG in malignant cases might be due to the recognition of "malignant danger", in line with its presumed role as a "pattern recognition molecule" [16]. We could not find any literature evaluating serum HRG protein or its expression levels in ALL.

\section{Conclusion}

All these findings indicated that HRG might be a novel diagnostic biomarker in ALL patients, with high sensitivity and specificity. The more significant positive correlations of HRG-serum protein over HRG-RNA and its easy method of application, motivate its application in large clinical studies as a potential prognostic marker.

\section{Acknowledgements}

Our thanks are due to all patients and healthy subjects involved in this study and to Clinical Hematology Unit, Faculty of Medicine, Ain Sham University for providing us the samples. This study was supported by grant No; 3380, 2015 from the Deanship of scientific research, Qassim University, Saudi Arabia.

\section{Conflict of Interest}

The authors declare that they have no competing interests.

\section{References}

[1] Faderl, S., O’Brien, S., Pui, C., Stock, W., Wetzler, M., Hoelzer, D., et al. (2010) Adult Acute Lymphoblastic Leukemia Concepts and Strategies. Cancer, 1165-1176. https://doi.org/10.1002/cncr.24862

[2] Zhao, Y., Huang, H. and Wei, G. (2013) Novel Agents and Biomarkers for Acute Lymphoid Leukemia. Journal of Hematology \& Oncology, 6, 40. https://doi.org/10.1186/1756-8722-6-40

[3] Faderl, S., O’Brien, S., Pui, C.H., Stock, W., Wetzler, M., Hoelzer, D., et al. (2010) Adult Acute Lymphoblastic Leukemia: Concepts and Strategies. Cancer, 116, 11651176. https://doi.org/10.1002/cncr.24862

[4] Jones, A.L., Hulett, M.D. and Parish, C.R. (2005) Histidine-Rich Glycoprotein: A Novel Adaptor Protein in Plasma That Modulates the Immune, Vascular and Coagulation Systems. Immunology \& Cell Biology, 83, 106-118. https://doi.org/10.1111/j.1440-1711.2005.01320.x

[5] Borza, D.B., Tatum, F.M. and Morgan, W.T. (1996) Domain Structure and Con- 
formation of Histidine-Proline-Rich Glycoprotein. Biochemistry, 35, 1925-1934. https://doi.org/10.1021/bi952061t

[6] Tugues, S., Roche, F., Noguer, O., Orlova, A., Bhoi, S., Padhan, N., et al. (2014) Histidine-Rich Glycoprotein Uptake and Turnover Is Mediated by Mononuclear Phagocytes. PLOS ONE, 9, e107483. https://doi.org/10.1371/journal.pone.0107483

[7] Johnson, L., Goubran, H. and Kotb, R. (2014) Histidine Rich Glycoprotein and Cancer: A Multi-faceted Relationship. Anticancer Research, 34, 593-603.

[8] Simantov, R., Febbraio, M. and Silverstein, R.L. (2005) Theantiangiogenic Effect of Thrombospondin-2 Is Mediated by CD36 and Modulated by Histidine-Rich Glycoprotein. Matrix Biology, 24, 27-34. https://doi.org/10.1016/j.matbio.2004.11.005

[9] Juarez, J.C., Guan, X., Shipulina, N.V., Plunkett, M.L. Parry, G.C., Elliot Shaw, D.E., et al. (2002) Histidine-Proline-Rich Glycoprotein Has Potent Antiangiogenic Activity Mediated through the Histidine-Proline-Rich Domain. Cancer Research, 62, 53445350.

[10] Kärrlander, M., Lindberg, N., Olofsson, T., Kastemar, M., Olsson, A.K. and Uhrbom, L. (2009) Histidine-Rich Glycoprotein Can Prevent Development of Mouse Experimental Glioblastoma. PLoS ONE, 4, e8536.

https://doi.org/10.1371/journal.pone.0008536

[11] Rolny, C., Mazzone, M., Tugues, S., Laoui, D., Johansson, I., Coulon, C., et al. (2011) HRG Inhibits Tumor Growth and Metastasis by Inducing Macrophage Polarization and Vessel Normalization through Down-Regulation of PlGF. Cancer Cell, 19, 31-44. https://doi.org/10.1016/j.ccr.2010.11.009

[12] Thulin, A., Ringvall, M., Dimberg, A., Karehed, K., Vaisanen, T., Vaisanen, M.R., et al. (2009) Activated Platelets Provide a Functional Microenvironment for the Antiangiogenic Fragment of Histidine-Rich Glycoprotein. Molecular Cancer Research, 7, 1792-1802. https://doi.org/10.1158/1541-7786.MCR-09-0094

[13] Bennettt, J.M., Catovsky, D. and Daniel, M.T. (1976) Proposals for the Classification of the Acute Leukaemias. French-American-British (FAB) Co-Operative Group. British Journal of Haematology, 3, 451-458. https://doi.org/10.1111/j.1365-2141.1976.tb03563.x

[14] Thomas, D.A., Faderl, S., Cortes, J., O’Brien, S., Giles, F.J., Kornblau, S.M., et al. (2004) Treatment of Philadelphia Chromosome-Positive Acute Lymphocytic Leukemia with Hyper-CVAD and Imatinibmesylate. Blood, 103, 4396-4407.

https://doi.org/10.1182/blood-2003-08-2958

[15] Gokbuget, N., Kneba, M., Raff, T., Trautmann, H., Bartram, C.R., Arnold, R., et al. (2012) Adult Patients with Acute Lymphoblastic Leukemia and Molecular Failure Display a Poor Prognosis and Are Candidates for Stem Cell Transplantation and Targeted Therapies. Blood, 120, 1868-1876.

[16] Poon, I.K., Hulett, M.D. and Parish, C.R. (2010) Histidine-Rich Glycoprotein Is a Novel Plasma Pattern Recognition Molecule That Recruits IgG to Facilitate Necrotic Cell Clearance via Fcgammari on Phagocytes. Blood, 115, 2473-2482. https://doi.org/10.1182/blood-2009-07-234013

[17] Matboli, M., Eissa, E. and Said, H. (2014) Evaluation of Histidine-Rich Glycoprotein Tissue RNA and Serum Protein as Novel Markers for Breast Cancer. Medical Oncology, 31, 897. https://doi.org/10.1007/s12032-014-0897-4

[18] Klenotic, P.A., Huang, P. and Palomo, J. (2010) Histidine-Rich Glycoprotein Modulates the Anti-Angiogenic Effects of Vasculostatin. American Journal of Pathology, 176, 2039-2050. https://doi.org/10.2353/ajpath.2010.090782

[19] He, X., Wang, Y., Zhang, W., Li, H., Luo, R., Zhou, Y., et al. (2014) Screening Differential Expression of Serum Proteins in AFP-Negative HBV-Related Hepatocellular 
Carcinoma Using iTRAQ-MALDI-MS/MS. Neoplasma, 61, 17-26. https://doi.org/10.4149/neo 2014001

[20] Wang, Y.S., Cao, R., Jin, H., Huang, Y.P., Zhang, X.Y., Congm, Q., et al. (2011) Altered Protein Expression in Serum from Endometrial Hyperplasia and Carcinoma Patients. Journal of Hematology \& Oncology, 4, 15. https://doi.org/10.1186/1756-8722-4-15

[21] Wu, J., Xie, X., Liu, Y., He, J., Benitez, R., Buckanovich, R.J., et al. (2012) Identification and Confirmation of Differentially Expressed Fucosylated Glycoproteins in the Serum of Ovarian Cancer Patients Using a Lectin Array and LC-MS/MS. Journal of Proteome Research, 11, 4541-4552. https://doi.org/10.1021/pr300330z

[22] Lee, C., Bongcam-Rudloff, E., Sollner, C., Jahnen-Dechent, W. and Claesson-Welsh, L. (2009) Type 3 Cystatins, Fetuins, Kininogen and Histidine-Rich Glycoprotein. Frontiers in Bioscience, 14, 2911-2922. https://doi.org/10.2741/3422

[23] Poon, I.K., Patel, K.K., Davis, D.S., Parish, C.R. and Hulett, M.D. (2011) Histidine-Rich Glycoprotein: The Swiss Army Knife of Mammalian Plasma. Blood, 117, 2093-2101. https://doi.org/10.1182/blood-2010-09-303842

[24] Ahmed, M.B., Shehata, H.H., Moussa, M. and Ibrahim, T.M. (2012) Prognostic Significance of Survivin and Tumor Necrosis Factor-Alpha in Adult Acute Lymphoblastic Leukemia. Clinical Biochemistry, 45, 112-126. https://doi.org/10.1016/j.clinbiochem.2011.08.1147

[25] Alkhouly, N., Shehata, I., Ahmed, M.B., Shehata, H., Hassan, S. and Ibrahim, T. (2013) HLA-G Expression in Acute Lymphoblastic Leukemia: A Significant Prognostic Tumor Biomarker. Medical Oncology, 30, 460. https://doi.org/10.1007/s12032-013-0460-8

[26] Nagafuji, K., Miyamoto, T., Eto, T., Kamimura, O., Taniguchi, S., Okamura, T., et al. (2013) Monitoring of Minimal Residual Disease (MRD) Is Useful to Predict Prognosis of Adult Patients with Ph-Negative ALL: Results of a Prospective Study (ALL MRD2002 Study). Journal of Hematology \& Oncology, 6, 14. https://doi.org/10.1186/1756-8722-6-14

[27] Roberts, A.S., Campa, M.J., Gottlin, E.B., Jiang, C., Owzar, K., Kindler, H.L., et al. (2012) Identification of Potential Prognostic Biomarkers in Patients with Untreated, Advanced Pancreatic Cancer from a Phase 3 Trial (Cancer and Leukemia Group B 80303). Cancer, 118, 571-578. https://doi.org/10.1002/cncr.26270

[28] Zhang, Q., Jiang, K., Li, Y., Gao, D., Sun, L., Zhang, S., et al. (2015) Histidine-Rich Glycoprotein Function in Hepatocellular Carcinoma Depends on Its $N$-Glycosylation Status, and It Regulates Cell Proliferation by Inhibiting Erk1/2 Phosphorylation. Oncotarget, 6, 30222-30231.

[29] Mantovani, A. and Sica, A. (2010) Macrophages, Innate Immunity and Cancer: Balance, Tolerance, and Diversity. Current Opinion in Immunology, 22, 231-237. https://doi.org/10.1016/j.coi.2010.01.009 


\section{Abbreviations}

$\begin{array}{ll}\text { ALL } & \text { Acute lymphoblastic leukemia } \\ \text { AUC } & \text { Area under ROC curve } \\ \text { BM } & \text { Bone marrow } \\ \text { ELISA } & \text { Enzyme-linked immunosorbent assay } \\ \text { HRG } & \text { Histidine-rich glycoprotein } \\ \text { LD } & \text { Lactate dehydrogenase } \\ \text { NPV } & \text { Negative predictive value } \\ \text { PPV } & \text { Positive predictive value } \\ \text { qPCR } & \text { Real-time polymerase chain reaction } \\ \text { ROC curve } & \text { Receiver operating characteristic curve. } \\ \text { TLC } & \text { Total leukocyte count }\end{array}$

Submit or recommend next manuscript to SCIRP and we will provide best service for you:

Accepting pre-submission inquiries through Email, Facebook, LinkedIn, Twitter, etc. A wide selection of journals (inclusive of 9 subjects, more than 200 journals)

Providing 24-hour high-quality service

User-friendly online submission system

Fair and swift peer-review system

Efficient typesetting and proofreading procedure

Display of the result of downloads and visits, as well as the number of cited articles

Maximum dissemination of your research work

Submit your manuscript at: http://papersubmission.scirp.org/

Or contact ojbd@scirp.org 